\title{
DNA looping in cellular repression of transcription of the galactose operon
}

\author{
Nitai Mandal, ${ }^{1}$ Wen Su, ${ }^{2}$ Roberta Haber, ${ }^{1}$ Sankar Adhya, ${ }^{1}$ and Harrison Echols ${ }^{2}$ \\ ${ }^{1}$ Laboratory of Molecular Biology, National Cancer Institute, National Institutes of Health, Bethesda, Maryland 20892 USA; \\ ${ }^{2}$ Department of Molecular and Cell Biology, University of California, Berkeley, California 94307 USA
}

\begin{abstract}
Communication between distant DNA sites is a central feature of many DNA transactions. Negative regulation of the galactose ( $\mathrm{gal}$ ) operon of Escherichia coli requires repressor binding to two operator sites located on opposite sides of the promoter. The proposed mechanism for regulation involves binding of the repressor to both operator sites, followed by a protein-protein association that loops the intervening promoter DNA (double occupancy plus association). To assess these requirements in vivo, we have previously converted gal operator sites to lac and shown that both operator sites must be occupied by the homologous repressor protein (Lac or Gal) for negative regulation of the gal operon. We have now addressed more directly the need for proteinprotein association by the use of the converted operator sites and a mutant Lac repressor defective in association of the DNA-binding dimers. We have compared the biological and biochemical activity of two Lac repressors: the wild-type (tetramer) $I^{+}$form, in which the DNA-binding dimer units are tightly associated; and the mutant $I^{\text {adi }}$ repressor, in which the dimer units do not associate effectively. The $I^{+}$repressor is an efficient negative regulator of the gal operon in vivo, but the $I^{\text {adi }}$ mutant is an ineffective repressor. Purified $\mathrm{I}^{+}$repressor efficiently forms DNA loops between operator sites that we have visualized by electron microscopy; the Idi repressor fails to form DNA loops, although the protein binds effectively to both operator sites. From the clear correlation between looping in vitro and repression in vivo, we conclude that regulation of the gal operon depends on the association of repressor proteins bound to the two operator sites. Repression is likely to involve a DNA-wound nucleoprotein complex in which RNA polymerase is present but unable to carry out a productive interaction with the promoter sequence.
\end{abstract}

[Key Words: DNA looping; galactose operon regulation; transcription; Lac repressor]

Received October 6, 1989; revised version accepted January 12, 1990.

Localization and control in many DNA transactions depend on the association of DNA-bound proteins to generate a multiprotein regulatory complex (Echols 1984, 1986; Adhya 1989). Stable, DNA-wound nucleoprotein structures typically control initiation of DNA replication and site-specific recombination (Echols 1984, 1986, 1990; Gellert and Nash 1987; Landy 1989|. In the formation of these higher order structures, an essential step is a communication between proteins bound to spatially separated DNA sites. For control of transcription, communication between distant regulatory sites is also thought to involve association between proteins with the consequence of looping the intervening DNA; these interactions may be transient or lead to a more stable complex with other proteins (Irani et al. 1983; Dunn et al. 1984; Majumdar and Adhya 1984; Echols 1986; Ptashne 1986; Schleif 1988; Adhya 1989; Mitchell and Tjian 1989|. Electron microscopic evidence has been presented for DNA-looping interactions involving $\lambda c \mathrm{I}$ (Griffith et al. 1986), LacI (Krämer et al. 1987), and the repressor for the deo operon (Amouyal et al. 1989). However, there has not been a study indicating the necessity for loop formation, rather than simple occupancy, for regulation of transcription in vivo. In the work reported here, we used the gal operon of Escherichia coli to provide a correlation between repression in a biological system in vivo and capacity for loop formation in vitro.

The gal operon is a valuable experimental system in which to study the interaction of noncontiguous regulatory proteins because negative regulation depends on two operator sites, $O_{E}$ and $O_{I}$ that are on opposite sides of the promoter (Fig. 1A) (Irani et al. 1983; Majumdar and Adhya 1984; Adhya 1987). The DNA looping model predicts that negative regulation requires interaction of DNA-bound proteins in addition to binding of the repressor to both operator sites (double occupancy plus association). We have so far been unable to detect stable association of purified $\mathrm{Gal}$ repressor dimers bound to the operator sites for the normal gal operon (Majumdar et al. 1987). Among several possibilities, the dimer-dimer interaction may occur only in the presence of RNA polymerase, as considered below. To examine whether the gal operon is regulated by double occupancy plus association, we used an experimental system in which the gal operator sites had been converted to lac operators, thus placing the gal operon under regulation by the Lac repressor (Haber and Adhya 1988). In contrast to the Gal repressor, the Lac repressor forms a stable tetramer, con- 
A.

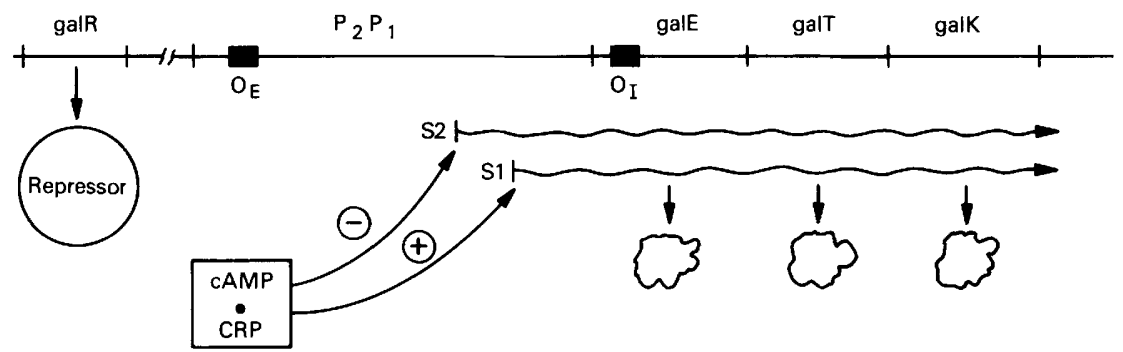

B.

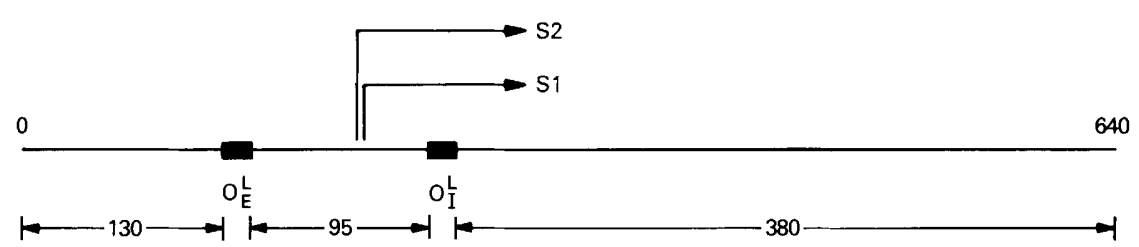

Figure 1. The gal operon of E. coli. $(A)$ The organization of the operon and its regulation by the positive regulator cAMP receptor protein (CRP) and the negative regulator GalR. The gal operon of $E$. coli has three structural genes, galE, galT, and galK, encoding, respectively, uridine diphosphogalactose-4-epimerase (epimerase), galactose-1-phosphate uridyltransferase (transferase), and galactokinase (for review, see Adhya 1987). The operon is subject to both positive and negative regulatory signals that control two promoters. $P_{1}$ and $P_{2}$. The $P_{1}$ promoter is activated by the positive regulator CRP in the presence of cAMP; the $P_{2}$ promoter is repressed by $\mathrm{CRP}$-cAMP. Both promoters are negatively regulated by the Gal repressor; effective repression by Gal repressor requires two operator sites, $O_{E}$ and $O_{I}$, which are on opposite sides of $P_{1}$ and $P_{2}$. Repression is relieved by the addition of D-galactose or its nonmetabolizable analog D-fucose. The structural genes, galE, galT, and galK, are not drawn to scale. The repressor is the product of the unlinked galR gene. $(B)$ Schematic scale drawing of the promoter-operator region on the restriction fragment used for analysis of DNA-repressor interactions by electron microscopy. The gal operators, $O_{E}$ and $O_{I}$, have been converted to lac operators $O_{E}^{L}$ and $O_{I}^{L}$.

sisting of two dimeric DNA-binding units (Kania and Müller-Hill 1977; Barkley and Bourgeois 1978; Whitson and Matthews 1986; Krämer et al. 1987). We compared the biological and biochemical activity of two Lac repressors: the wild-type tetramer $\left(\mathrm{I}^{+}\right)$; and the mutant repressor ( ${ }^{\text {adi }}$ ), in which the dimer units do not associate effectively. The $\mathrm{I}^{+}$repressor is an effective regulator of the gal operon, and purified $\mathrm{I}^{+}$repressor forms DNA loops visible in the electron microscope. The $I^{\text {adi }}$ mutant is an ineffective regulator in vivo, and purified $\mathrm{I}^{\text {adi }}$ repressor fails to form DNA loops, although the protein binds efficiently to both operator sites. These experiments show that negative regulation of the converted gal operon depends on the association of DNA-bound repressor proteins. We therefore believe that repression of the homologous normal gal operon depends on DNA looping as well.

\section{Results}

\section{Repressor mutant defective in tetramer formation}

In studying the mechanism of Gal repressor action, we previously modified the operator sites to show that occupancy of both operator sites alone is not sufficient for repression (Harber and Adhya 1988). Replacement of either $O_{E}$ or $O_{I}$ by a lac operator $\left(O_{E}^{L} O_{I}^{G}\right.$ or $\left.O_{E}^{G} O_{I}^{L}\right)$ results in constitutive expression of the gal operon even in the presence of excess $\mathrm{Gal}$ and Lac repressors. However, re- placement of both $O_{E}$ and $O_{I}$ by lac operator $\left(O_{E}^{L} O_{I}^{L}\right)$ fully restores repression. This converted gal operon is now inducible by isopropyl- $\beta$-D-thiogalactoside (IPTG), the inducer of the lac operon. Gal repressor and D-galactose for $D$-fucose) do not have any effect on expression of the modified gal operon. A plausible explanation of these results is that repression requires a communication between two operators through interaction of bound proteins. Only like repressors (Gal-Gal or Lac-Lac) can interact, presumably through formation of a tetramer by association of DNA-bound dimers. Such a communication would necessarily generate a DNA loop. To provide a biochemical test of the need for double occupancy plus association, we studied the properties of a Lac repressor mutant that is defective in the association of the DNAbinding dimer units into the normal tetramer.

Mutant Lac repressors have been described that are defective in tetramer formation but retain the ability to repress the lac operon (Miller 1978; Lehming et al. 1988). We studied one of these mutations ( $I^{\text {adi }}$; Lehming et al. 1988). By DNA sequence analysis, the 1 acI ${ }^{\text {adi }}$ gene has a single-base deletion, creating a frameshift mutation in the 330th codon of the 360 in the lacI gene. The resultant mutant repressor $\left(\mathrm{I}^{\text {adi}}\right)$ has replaced the 31 carboxyl-terminal amino acids with a 16 amino-acid segment of a different sequence. The wild-type sequence is LAPNTQTASPRALADSLMQLARQVSRLESGQ; the deduced mutant sequence is WRPIRKPPLPARWPIH. 
We purified the $\mathrm{I}^{+}$and $\mathrm{I}^{\text {adi }}$ repressors (N. Mandal and S. Adhya, in prep.); the assay used for purification was based on the ability of the repressor to bind ${ }^{14} \mathrm{C}$-labeled IPTG (Gilbert and Müller-Hill 1966). The amino-terminal amino acid sequences of the repressors were confirmed by Edman degradation in an Applied Biosystems model 477A analyzer. The molecular weight of the mutant and wild-type repressor was estimated by gel filtration (Fig. 2). The Idi repressor eluted as expected for a tetramer $(\sim 150 \mathrm{kD})$. The I Idi repressor eluted as expected for a protein of $\sim 65 \mathrm{kD}$, close to the calculated molecular mass of a dimer (74 kD). A similar molecular mass was estimated from glycerol gradient sedimentation (data not shown). We conclude that the Idi mutant is proficient in dimer formation but fails to effectively carry out the association of the dimer units into a tetramer. Presumably, the carboxy-terminal amino acids are important for dimer-dimer association (Miller 1978). The Idi mutant exhibited normal binding to $O_{E}^{L}$ or $O_{I}^{L}$ operator sites, as judged by gel mobility assays $(C$. Zwieb and S. Adhya, unpubl.) and electron microscopy (see Table 3, below).

\section{Ineffective repression of the gal operon by the LacI adi repressor in vivo}

To test the ability of the $\mathrm{I}^{\text {adi }}$ mutant repressor to repress the gal operon in vivo, several $E$. coli strains with different alleles of the lacI gene were constructed. A bacterial strain in which the $O_{I}$ locus (located internal to the gale structural gene) has been converted to a lac operator sequence assumes $\mathrm{a} \mathrm{Gal}^{-}$phenotype because the re-

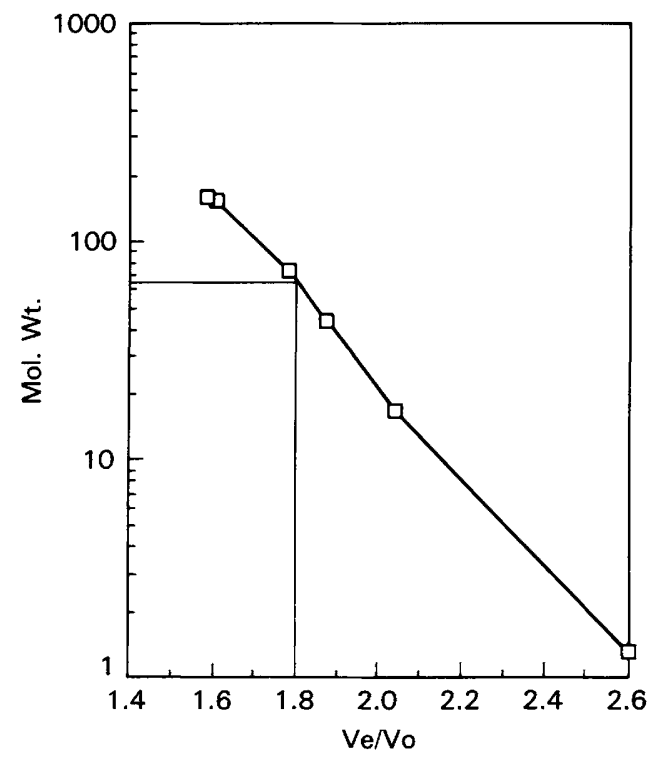

Figure 2. Elution pattern of Lac repressor in FPLC gel-filtration. The column fractionation included a mixture of proteins with known molecular weights. The order of elution was globulin (158 kD), wild-type Lac repressor (154 kD), Gal repressor (74 kD), mutant Lac repressor (estimated size $65 \mathrm{kD}$ ), ovalbumin (44 kD), myoglobin (17 kD), and vitamin $B_{12}(1.3 \mathrm{kD})$. quired base pair changes inactivate the epimerase activity (Haber and Adhya 1988). However, the regulatory capacity of an operon with both operators converted can be studied by following the expression of one of the other two gene products, transferase or galactokinase. Table 1 shows the results of galactokinase assays of strains carrying $\mathrm{I}^{+}, \mathrm{I}^{-}$, or $I^{\text {adi }}$ alleles of the lacI gene. Whereas $\mathrm{LacI}^{+}$repressor caused, as expected, full repression (50-fold) of the gal operon (line 2), there was only 2.3 -fold repression in the presence of the Idi $^{\text {adi }}$ mutant repressor (line 3). Addition of IPTG yielded full derepression in both strains. The derepressed levels of galactokinase were identical to those observed in a strain carrying a $\operatorname{Tn} 10$ insertion mutation in the lacI gene. The small repression of gal by the $I^{\text {adi }}$ mutant presumably occurs because an $O^{E}$-bound repressor has some limited capability to repress the system. This is consistent with previous work, which showed that $O_{E}^{G} O_{I}^{L}$ was partially repressed by GalR and $O_{E}^{G} O_{I}^{L}$ was partially repressed by LacI (Haber and Adhya 1988). From the galactokinase data, we conclude that a Lac repressor dimer is ineffective in repressing the gal operon.

The failure of the $\mathrm{I}^{\text {adi }}$ repressor to repress efficiently the gal operon might result from ineffective binding to lac operators rather than inability to associate after binding. To examine this point, we studied repression of the lac operon. If the dimer mutant binds effectively to the operator, the mutant repressor is expected to be an effective repressor of the lac operon, which is considered to be controlled at least primarily by a single operator (Reznikoff et al. 1985). We observed highly efficient repression of the lac operon (Table 1, line 3). However, the Idi mutant was not totally effective; compared to wildtype repression ( $\sim 2000$-fold), there was $\sim 300$-fold repression of $\beta$-galactosidase. The small loss of repression is expected from a weak double operator effect in the lac operon because of the existence of two other operator sequences $\left(\mathrm{O}_{2}\right.$ and $\left.\mathrm{O}_{3}\right)$ (Reznikoff et al. 1974; Gilbert et al. 1975; Mossing and Record 1986; Eisman et al. 1987; Flashner and Gralla 1988); (for review, see Adhya 1989). This expectation is supported by the previous observation that a mutation in $\mathrm{O}_{2}$ yields $3 \%$ derepression of the lac operon (Eisman et al. 1987). In more recent work done concurrently with our own, Oehler et al. (1990) have found that the introduction of both $\mathrm{O}_{2}{ }^{-}$and $\mathrm{O}_{3}{ }^{-}$ mutations into a $\mathrm{lacI}^{+}$background gives the same derepression as the $l a c I^{\text {adi }}$ mutation and that the derepression found with $1 a c I^{\text {adi }}$ is not increased by an additional $\mathrm{O}_{2}-$ mutation.

To be sure that even overproduction of LacI ${ }^{\text {adi }}$ would fail to repress the gal operon, we have studied the repression of the gal and lac operons under conditions of overproduction of the repressors from a multicopy plasmid (Table 2). Under these conditions, there was complete repression of the lac operon; $\beta$-galactosidase level allowed by the mutant repressor was the same as that allowed by the wild-type repressor. Similar results for lac repression by the multicopy plasmid have been obtained previously (Lehming et al. 1988). In the same cells, the mutant repressor brought about only a three- 
Table 1. Activity of LacI ${ }^{\text {adi }}$ repressor with modified gal operon and normal lac operon

\begin{tabular}{|c|c|c|c|c|c|c|c|}
\hline \multirow[b]{2}{*}{ Strain } & \multirow{2}{*}{$\begin{array}{l}\text { Lac repressor } \\
\text { genotype }\end{array}$} & \multicolumn{2}{|c|}{$\begin{array}{c}\text { Activity of } \\
\text { galactokinase } \\
\end{array}$} & \multirow{2}{*}{$\begin{array}{l}\text { Repression } \\
\text { ratio }\end{array}$} & \multicolumn{2}{|c|}{$\begin{array}{c}\text { Activity of } \\
\beta \text {-galactosidase } \\
\end{array}$} & \multirow{2}{*}{$\begin{array}{l}\text { Repression } \\
\text { ratio }\end{array}$} \\
\hline & & $-I$ & ${ }^{+} I$ & & $-\mathrm{I}$ & ${ }^{+} \mathrm{I}$ & \\
\hline NM18 & $\operatorname{lacI}:: \operatorname{Tn} 10$ & 31 & 29 & 1.0 & 8.2 & 8.2 & 1.0 \\
\hline NM17 & $\operatorname{lacI}^{+}$ & 0.6 & 32 & 53 & 0.004 & 7.8 & 1950 \\
\hline NM138 & $\operatorname{lacl^{adi}}$ & 13 & 30 & 2.3 & 0.023 & 7.4 & 320 \\
\hline
\end{tabular}

-I and ${ }^{+}$I represent the absence and presence of IPTG, respectively, in the medium during cell growth. The units of galactokinase are nanomoles of galactose-1-phosphate formed per minute per milliliter of cells of $\mathrm{A}_{600}=1.0$; the units of $\beta$-galactosidase are nanomoles of $O$-nitrophenyl galactoside hydrolyzed per minute per milliliter of cells of $A_{600}=1.0$. The repression ratio is the activity with inducer divided by the activity without inducer.

fold repression of the gal operon; the gal operon repression was similar to that obtained in the presence of $\mathrm{mu}$ tant repressor made from a single chromosomal gene. These results show clearly that the failure of the Iadi repressor to repress the gal operon does not result from inefficient binding to the operators. In Table 2, the repressed level of gal expression by the wild-type tetramer repressor has increased slightly. This small derepression by overproduced Lac repressor is not surprising because DNA looping depends on the associating of a single tetramer with both operators (shown in vitro by Krämer et al. 1987). If a different LacI tetramer occupies each operator most of the time, looping will be reduced.

We have also demonstrated that the $\mathrm{I}^{\text {adi }}$ mutant provides effective repression of $l a c$ but not gal by a sensitive genetic assay for repression. As noted above, an $O^{L}$ sequence at the $O_{I}$ operator changes the galE sequence and results in an inactive epimerase protein. If the enzymes transferase and galactokinase are expressed in the absence of active epimerase, the cells are killed when galactose is present in the growth medium (Nikaido 1961); phosphorylated galactose intermediates cause bacteriolysis. Thus, sensitivity to galactose indicates operon expression, and resistance means repression (Haber and Adhya 1988|. The results of galactose sensitivity tests in the presence of overproduced repressors are also shown in Table 2. The gal $O_{E}^{L} O_{I}^{L}$ strain in the absence of repressor grew normally in $0.3 \%$ glycerol media but was highly sensitive to the presence of $0.01 \%$ galactose. Wild-type repressor made the strain galactose-resistant, showing repression. However, the survival of the strain in the presence of galactose with mutant repressor was the same as with no repressor $\left(\sim 10^{-6}\right.$; mutation fre- quency). This result confirms the inability of even a high level of the mutant repressor to bring about normal repression. A similar assay for lac operon expression gave contrasting results. The cells were resistant to phenylgalactoside in the presence of excess wild-type or mutant repressor. Phenylgalactoside is a substrate of $\beta$-galactosidase, but not an inducer of the lac operon (Beckwith 1978). If the lac operon is not repressed, phenylgalactoside would be hydrolyzed by $\beta$-galactosidase to generate galactose, which would kill the cells with a derepressed galE- operon. A sensitivity to the galactoside would mean simultaneous derepression of both the gal and lac operons, and a resistance would reflect repression of at least one. Because the mutant repressor fails to repress gal, the resistance of the cells carrying the mutant repressor to phenylgalactoside means repression of the lac operon.

\section{DNA loop formation by $\mathrm{LaCI}^{+}$but not LacI ${ }^{a d i}$ repressor}

The critical test of the role of double occupancy plus protein association is direct visualization by electron microscopy of looped DNA between the two operator sites. As shown in Figure 1B, the expected loop length is the $95 \mathrm{bp}$ between the two operator sites. We observed efficient loop formation by the $\mathrm{I}^{+}$repressor but not by the $\mathrm{I}^{\text {adi }}$ mutant. Figure 3 shows examples of looped DNA structures formed by the $\mathrm{I}^{+}$repressor. Based on the length of the restriction fragment, the looped structures are expected to have a short tail of $130 \mathrm{bp}$, a long tail of $380 \mathrm{bp}$, and a loop of $95 \mathrm{bp}$ (Fig. 1B). Quantitative measurements are presented in Figure 4. The measured lengths are very close to those predicted. DNA loop for-

Table 2. Effect of excess repressor on expression of gal and lac operons

\begin{tabular}{lcccccc}
\hline \multirow{2}{*}{$\begin{array}{l}\text { Repressor } \\
\text { from plasmid }\end{array}$} & \multicolumn{2}{c}{ Enzyme activity } & & \multicolumn{2}{c}{ EOP with glycerol plus } \\
\cline { 2 - 3 } \cline { 5 - 6 } & galactokinase & $\beta$-galactosidase & & nothing & Gal & $\phi$-Gal \\
\hline None & 24.5 & 3.7 & & 1.0 & $\sim 10^{-6}$ & $\sim 10^{-6}$ \\
LacI $^{+}$ & 2.0 & 0.012 & & 1.0 & 1.0 & 1.0 \\
LacI $^{a d i}$ & 7.7 & 0.010 & & 1.0 & $\sim 10^{-6}$ & 1.0 \\
\hline
\end{tabular}

Cell growth and enzyme assays were done as described in Materials and methods, except that $50 \mu \mathrm{g} / \mathrm{ml}$ of ampicillin was present in the growth medium. The units of galactokinase and $\beta$-galactosidase activity are as defined in Table 1 . The host strain carrying the plasmids is the lacI deletion NM79. Galactose sensitivity tests were done as described in Materials and methods. (Gal) D $(+\mid$ galactose; ( $\phi$-Gal) phenyl- $\beta$-D-galactoside; (EOP) efficiency of colony formation. 

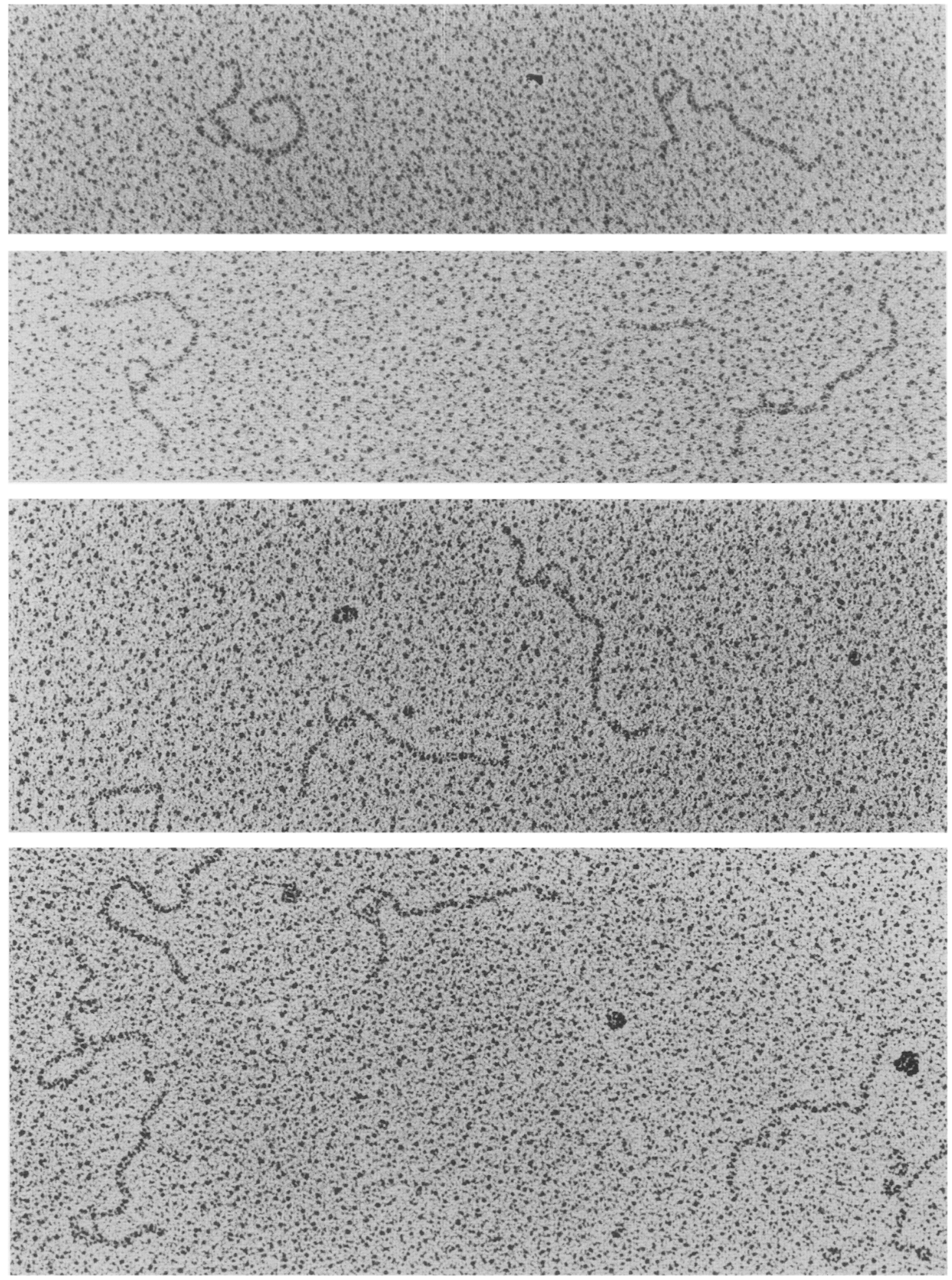

Figure 3. Electron micrographs of the looped molecules formed by LacI ${ }^{+}$repressor and converted gal operators $O_{E}^{L}$ and $O_{I}^{L}$. Each of the top three micrographs has two looped molecules; the bottom one has three looped molecules. The length of the DNA molecule is $640 \mathrm{bp}$.

mation by $\mathrm{I}^{+}$repressor between two lac operator sites has been demonstrated previously (Krämer et al. 1987).

Quantitative data on repressor-binding and loop formation are presented in Table 3. DNA molecules were scored for the presence of one bound repressor, two bound repressors, and DNA loops. No loops were found for the Iadi repressor, although single and double operator binding was observed. We also observed the expected 

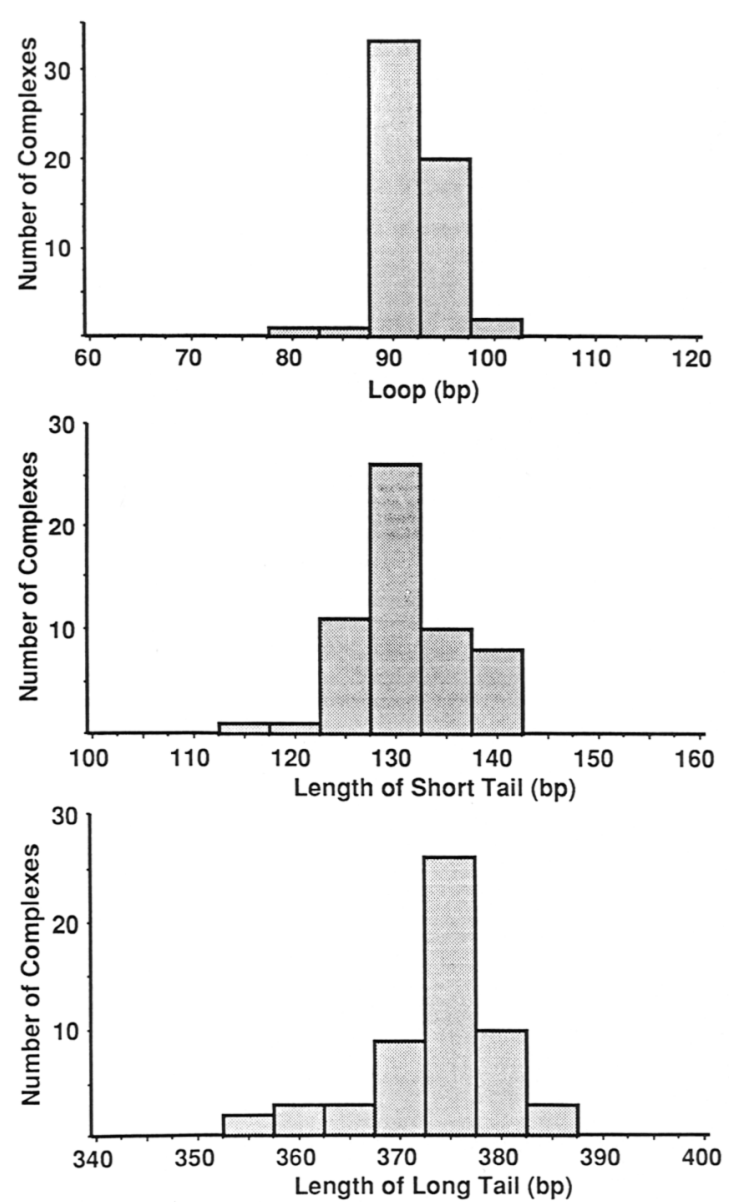

Figure 4. Measurements of looped molecules. The length of images from projections of photographed DNA molecules was measured on a Numonics 2400 digitizing board. The digitizer was calibrated by the length of the free DNA molecule, which is $640 \mathrm{bp}$.

electrophoretic patterns for single and double operator binding by the Iadi mutant in a gel retardation assay /data not shown). From the data for Figure 4 and Table 3, we conclude that the $\mathrm{I}^{\text {adi }}$ repressor dimer binds to operator sites but fails to mediate DNA looping by association of bound repressor dimers.

\section{Discussion}

Transcriptional control by association of DNA-bound regulatory proteins

The "classical model" for negative regulation of gene expression presumed that repressors block productive binding of RNA polymerase at the promoter site because the two proteins occupy overlapping segments of DNA (steric hindrance); (Reznikoff et al. 1985). However, more complex modes of regulation involving multipartite operators are demanded for the bacterial gal operon, and for the ara (Dunn et al. 1984) and deo operons (Valentin-Hansen et al. 1986). As noted above, even the paradigm lac operon may use a second operator site for full repression. Negative regulation in yeast can also occur from distant sites (Brand et al. 1985; Johnson and Herskowitz 1985; Hofmann et al. 1989). Thus, we believe that negative regulation by the classical model is likely to be rare.

Previous work has led to the proposal that proteins bound to noncontiguous regulatory sites may communicate with each other by protein-protein association, looping out the intervening DNA (Irani et al. 1983; Dunn et al. 1984; Majumdar and Adhya 1984). For the initiation of DNA replication and site-specific recombination, there is abundant evidence that communication occurs by the association of DNA-bound proteins in a nucleoprotein structure in which the DNA is looped or wound (Echols 1984, 1986, 1990; Gellert and Nash 1987; Landy 1989). Direct evidence by electron microscopy has been presented for interaction of DNA-bound proteins in the case of $\lambda c \mathrm{I}$ (Griffith et al. 1986), LacI (Krämer et al. 1987), and deo operon repressors (Amouyal et al. 1989). However, these demonstrations did not directly correlate DNA looping with repression in a biological system.

By the work on the gal operon described here, we have provided a direct correlation between repression activity in vivo and association of DNA-bound repressor proteins in vitro. The $\mathrm{I}^{+}$tetramer repressor is an effective negative regulator in cells, and purified $\mathrm{I}^{+}$protein forms DNA loops between the two operator sites. The Iadi dimer repressor is ineffective in vivo, and purified Iadi protein fails to form DNA loops. We have concluded that negative regulation of the modified gal operon requires the association of DNA-bound repressor proteins. We believe that this conclusion applies to the normal gal operon as well because the regulatory properties of the converted operon are identical to those of the normal gal operon (except for the switch of repressor proteins).

\section{Possible transcriptional control by an organized nucleoprotein structure}

As noted above in the introduction to the gal operon, regulated expression depends on an array of positive and

Table 3. DNA-protein complexes formed by $\mathrm{LacI}^{+}$and LacI ${ }^{\text {adi }}$ repressors

\begin{tabular}{|c|c|c|c|c|c|c|c|c|}
\hline \multirow[b]{2}{*}{ Protein } & \multicolumn{2}{|c|}{ Free DNA } & \multicolumn{2}{|c|}{$\begin{array}{c}\text { Single } \\
\text { binding }\end{array}$} & \multicolumn{2}{|c|}{$\begin{array}{l}\text { Tandem } \\
\text { binding }\end{array}$} & \multicolumn{2}{|c|}{ Loop } \\
\hline & I & $\overline{\text { II }}$ & I & $\overline{\text { II }}$ & I & $\overline{\mathrm{II}}$ & I & $\overline{\mathrm{II}}$ \\
\hline $\operatorname{LacI}^{\text {adi }}$ & 42 & 31 & 44 & 52 & 14 & 17 & 0 & 0 \\
\hline $\mathrm{LacI}^{+}$ & 53 & 54 & 29 & 34 & 3 & 1 & 15 & 11 \\
\hline
\end{tabular}

The experiments presented counted 100 molecules for each repressor. The DNA was $0.2 \mathrm{nM}$. In experiment $\mathrm{I}_{\text {, } \mathrm{LaCI}^{+}}$was 0.8 $\mathrm{nM}$, and LacI adi was $1.6 \mathrm{nM}$ to equalize concentration of dimer DNA-binding units. In experiment II, $\mathrm{LacI}^{+}$was $0.4 \mathrm{nM}$ and $\mathrm{LacI}^{\text {adi }}$ was $3.2 \mathrm{nM}$. Six experiments were done with $\mathrm{LacI}^{+}$over a fourfold concentration range; the number of loop structures ranged from 10 to $21 \%$. In four independent LacI ${ }^{\text {adi }}$ experiments over a similar concentration range, no loop structures were seen out of 400 examined. Single-binding refers to one bound repressor on the DNA; tandem-binding refers to two bound repressors. 
negative interactions involving RNA polymerase, CRPcAMP, and Gal repressor. We have not been able to demonstrate the DNA-looping interaction with purified Gal repressor protein, which exists in solution as a dimer. One possible explanation is that the DNA loop for Gal repressor normally forms in a multiprotein complex with RNA polymerase and CRP-cAMP (Adhya 1989). In this model (Fig. 5), all of the proteins involved in regulated transcription are present together on the DNA. Such an organized nucleoprotein structure may be facilitated by the demonstrated ability of both Gal and Lac repressors and CRP-cAMP to induce bending in DNA (Wu and Crothers 1984; Zwieb et al, 1989). The possibility of the multiprotein complex is supported by data from DNase footprinting, which indicate that repressor, CRP, and RNA polymerase can all be present together on the DNA (Adhya and Majumdar 1987; Kuhnke et al. 1989|. An organized nucleoprotein complex involving RNA polymerase and CRP-cAMP has also been suggested by Buc (Buc 1986). Evidence has also been presented that Lac repressor and RNA polymerase both occupy the lac promoter-operator region at the same time (Straney and Crothers 1987).

In the model proposed in Figure 5, there are two general ways in which inhibition of transcription may occur, both involving the capacity of RNA polymerase to execute a productive interaction at the promoter site. In one mechanism, the DNA loop provides a topological constraint on the promoter segment; RNA polymerase cannot proceed from the closed complex to the productive open complex because the requisite DNA unwinding cannot occur. The topological constraint model
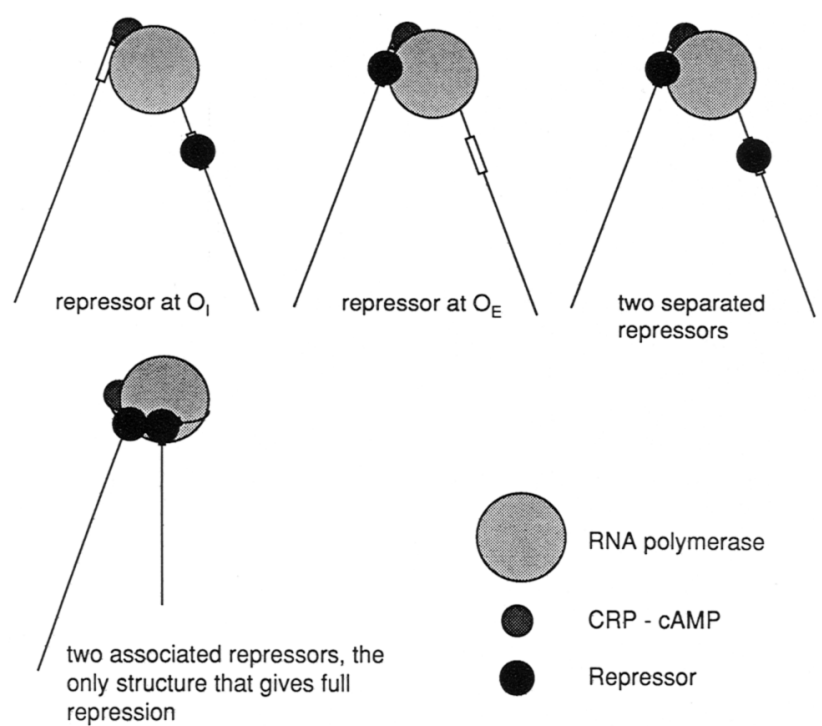

Figure 5. Model for regulation of the gal operon. The nucleoprotein structure active in negative regulation contains all of the regulatory proteins. The light gray sphere is RNA polymerase; the solid spheres are repressor; the dark gray sphere is CRP; the line represents duplex DNA; and the rectangle in the DNA represents an operator site. The two-repressor looped complex blocks initiation of transcription by RNA polymerase. requires that the interaction sites must be close. Alternatively (or in addition), one or both of the bound repressor molecules may alter the conformation of RNA polymerase by direct contact to impede formation of the open complex, initiation, or promoter clearance. By this mechanism, binding of one repressor to the operator closest to the promoter, $O_{E}$, may serve to provide a partial repression (e.g., the slight repression found with the Iadi repressor).

In summary, we conclude that the association of DNA-bound repressor proteins regulates the gal operon, probably in a DNA-wound nucleoprotein complex. The proposed mechanism is likely to be an example of the most general way in which DNA transactions are localized and controlled.

\section{Materials and methods}

Strains of E. coli $K-12$

NM17:F- $h s d S 20\left(r_{B}{ }^{-} m_{B}{ }^{-}\right)$ara 14 xyl5 mt11 leu $r p s L 20$ galO $O_{E}^{L} O_{I}^{L}$; NM18; NM17 lacI :: Tn10; NM138; NM17lacIadi; NM79; NM17 (lacI) $\Delta \mathrm{U} 169$ proC.

\section{Enzyme assays}

Cells were grown at $32^{\circ} \mathrm{C}$ to mid-log phase in minimal M56 media (Monod et al. 1951), containing $0.3 \%$ fructose, $0.1 \%$ casamino acids, and $1 \mu \mathrm{g} / \mathrm{ml}$ thiamine. Galactokinase (Adhya and Miller 1979) and $\beta$-galactosidase (Miller 1972) assays were performed as described previously. Lac repressor was assayed in 10 $\mathrm{mM}$ Tris- $\mathrm{HCl}(\mathrm{pH} 7.4)$, containing $10 \mathrm{~mm}$ magnesium-acetate, $200 \mathrm{~mm} \mathrm{KCl}, 0.1 \mathrm{mmEDTA}$, and $6 \mathrm{~mm}$ 2-mercaptoethanol.

\section{Galactose sensitivity}

For galactose sensitivity tests, cells were grown at $32^{\circ} \mathrm{C}$ in LB medium containing $50 \mu \mathrm{g} / \mathrm{ml}$ of ampicillin to $5 \times 10^{8}$ cells $/ \mathrm{ml}$ and then plated after various dilutions on M56 minimal agar plates, containing $0.3 \%$ glycerol, $0.1 \%$ casamino acids, $1 \mu \mathrm{g} / \mathrm{ml}$ of thiamine and, when added, $0.01 \%$ galactose or phenyl- $\beta-D-$ galactoside. The plates were incubated for $48 \mathrm{hr}$ and then counted for number of colonies. Efficiency of plating (EOP) represents the ratio of the colony-forming ability of a strain on a given plate to that of a control strain carrying plasmid pBR322 on glycerol plates in the absence of galactose or phenyl- $\beta$-D-galactoside. Phenylgalactoside is a substrate of $\beta$-galactosidase but not an inducer of the lac operon (Beckwith 1978); phenylgalactoside is hydrolyzed to generate galactose if the lac operon is expressed constitutively in the cells.

\section{Gel-filtration chromatography}

A Superose-12 column (25-ml bed volume) was washed twice with sterile deionized water and then equilibrated with $75 \mathrm{~mm}$ potassium phosphate buffer ( $\mathrm{pH} 7.4$ ) containing $5 \%$ glucose, 1 $\mathrm{mM}$ EDTA, $1 \mathrm{mM}$ DTT, $50 \mu \mathrm{g} / \mathrm{ml}$ of PMSF, and $0.4 \mathrm{M} \mathrm{KCl}$. The equilibration was done by passing two column volumes of the buffer at a flow rate of $0.2 \mathrm{ml} / \mathrm{min}$. The column was then loaded with a mixture of proteins that included the mutant Lac repressor. The elution was performed at a flow rate of $0.4 \mathrm{ml} / \mathrm{min}$. Elution was monitored by following optical absorbency at 280 $\mathrm{nm}\left(A_{280}\right)$. The mixture of proteins with known molecular weights are described in the legend to Figure 2. 


\section{Electron microscopy}

The DNA fragment (Fig. 1B) was cut from plasmid pH108, which contains the 640-bp region of gal DNA cloned between the EcoRI and HindIII sites of pBR322. The fragment was isolated from a $1.5 \%$ agarose gel. DNA-binding reactions $(10 \mu l)$ contained $10 \mathrm{~mm}$ Tris- $\mathrm{HCl}(\mathrm{pH} 8.0), 10 \mathrm{~mm} \mathrm{KCl}, 10 \mathrm{~mm}$ $\mathrm{Mg}(\mathrm{Ac})_{2}, 0.1 \mathrm{mM}$ EDTA, $0.1 \mathrm{~mm}$ DTT, $0.2-1 \mathrm{~mm}$ DNA /purified $O_{E}^{L} O_{I}^{L}$ fragment), and $0.2-8 \mathrm{nM} \mathrm{LacI}{ }^{+}$or $\mathrm{LacI}^{\text {adi }}$ repressor. The reaction mixtures were incubated for $20 \mathrm{~min}$ at room temperature and then put on grids without dilution or fixation. Electron microscopy was carried out by the polylysine technique (Williams 1977). Grids were rotary-shadowed with tungsten.

\section{Acknowledgments}

We thank B. Müller-Hill for the gift of plasmid pBW100 harboring the lacI adi mutation, Claude Klee for amino acid sequence analysis, Rick Eisner for editorial assistance, and Carol Gross for comments on the manuscript. Work at the University of California at Berkeley was supported by a grant from the $\mathrm{Na}$ tional Institutes of Health (GM-17078).

\section{References}

Adhya, S. 1987. The galactose operon. In Escherichia coli and Salmonella typhimurium (ed. F.C. Neidhardt), pp. 1503-1512. American Society for Microbiology, Washington, D.C.

. 1989. Multipartite genetic control elements: Communication by DNA loop. Annu. Rev. Genet. 23:227-250.

Adhya, S. and A. Majumdar. 1987. Negative control of the gal operon. In RNA polymerase and regulation of transcription (ed. W.S. Reznikoff, R.R. Burgess, J.E. Dahlberg, C.A. Gross, M.T. Record, and M.P. Wickens), pp. 129-135. Elsevier Science, New York.

Adhya, S. and W. Miller. 1979. Modulation of the two promoters of the galactose operon of Escherichia coli. Nature 279: 492-494.

Amouyal, M., L. Mortensen, H. Buc, and K. Hammer. 1989. Single and double loop formation when $d e o R$ repressor binds to its natural operator sites. Cell 58: 545-551.

Barkley, M.D. and S. Bourgeois. 1978. Repressor recognition of operator and effectors. In The operon (ed. J.H. Miller, and W.S. Reznikoff), pp. 177-220. Cold Spring Harbor Laboratory Press, Cold Spring Harbor, New York.

Beckwith, J.R. 1978. lac: The genetic system. In The operon (ed. J.H. Miller and W.S. Reznikoff), pp. 11-30. Cold Spring Harbor Laboratory Press, Cold Spring Harbor, New York.

Brand, A.H. L. Breeden, J. Abraham, R. Sternglanz, and K. Nasmyth. 1985. Characterization of a "silencer" in yeast: A DNA sequence with properties opposite to those of a transcriptional enhancer. Cell 41: 41-48.

Buc, H. 1986. Mechanism of activation of transcription by the complex formed between cyclic AMP and its receptor in Escherichia coli. Biochem. Soc. Trans. 14: 196-199.

Dunn, T.M., S. Hahn, S. Ogden, and R.F. Schleif. 1984. An operator at -280 base pairs that is required for repression of ar$a B A D$ operon promoter: Addition of DNA helical turns between the operator and promoter cyclically hinders repression. Proc. Natl. Acad. Sci. 81: 5017-5020.

Echols, H. 1984. Specialized nucleoprotein structures in high-fidelity DNA transactions. Bio Essays 1: 148-152.

- 1986. Multiple DNA-protein interactions governing high-precision DNA transactions. Science 233: 1050-1056. . 1990. Replication and recombination: Meeting sum- mary. In Molecular mechanisms in DNA replication and recombination (ed. C. Richardson and R. Lehman). pp. 1-31. Alan R. Liss, New York.

Eisman, E., B. von Wilcken-Bergmann, and B. Müller-Hill. 1987. Specific destruction of the second lac operator decreases repression of the lac operon in Escherichia coli fivefold. J. Mol. Biol. 195: 949-952.

Flashner, Y. and J.D. Gralla. 1988. Dual mechanism of repression at a distance in the lac operon. Proc. Natl. Acad. Sci. 85: 8969-8972.

Gellert, M. and H. Nash. 1987. Communication between segments of DNA during site-specific recombination. Nature 328: $401-404$.

Gilbert, W. and B. Müller-Hill. 1966. Isolation of the lac repressor. Proc. Natl. Acad. Sci. 56: 1891-1898.

Gilbert, W., J. Gralla, J. Majors, and A. Maxam. 1975. The chemical effects of nucleic acid alkylation and their relation to mutagenesis and carcinogenesis. In Protein ligand interactions (ed. H. Sund and G. Blauer), pp. 193-210. de Gruyter, Berlin.

Griffith, J., A. Hochschild, and M. Ptashne. 1986. DNA loops induced by cooperative binding of $\lambda$ repressor. Nature 322: 750-752.

Haber, R. and S. Adhya. 1988. Interaction of spatially separated protein-DNA complexes for control of gene expression: Operator conversion. Proc. Natl. Acad. Sci. 85: 9683-9687.

Hofmann, J.F., T. Laroche, A.H. Brand, and S.M. Gasser. 1989. RAP-1 factor is necessary for DNA loop formation in vitro at the silent mating type locus HML. Cell 57: 725-737.

Irani, M., L. Orosz, and S. Adhya. 1983. A control element within a structural gene: The gal operon of Escherichia coli. Cell 32: 783-788.

Johnson, A.D. and I. Herskowitz. 1985. A repressor (MAT 22 product) and its operator control expression of a set of cell type specific genes in yeast. Cell 42: 237-247.

Kania, J. and B. Müller-Hill. 1977. Construction, isolation and implications of repressor-galactosidase- $\beta$.galactosidase hybrid molecules. Eur. J. Biochem. 79: 381-386.

Krämer, H., M. Niemöller, M. Amouyal, B. Revet, B.v. Wilcken-Bergmann, and B. Müller-Hill. 1987. lac repressor forms loops with linear DNA carrying two suitably spaced lac operators. $E M B O$ / 6: $1481-1491$.

Kuhnke, G., C. Theres, H. Fritz, and R. Ehring. 1989. RNA polymerase and gal repressor bind simultaneously and with DNA bending to the control region of the Escherichia coli galactose operon. EMBO I. 8: 1247-1255.

Landy, A. 1989. Dynamic, structural and regulatory aspects of $\lambda$ site-specific recombination. Annu. Rev. Biochem. 58: 913950.

Lehming, N., J. Sartorius, S. Oehler, B. von Bilcken-Bergmann, and B. Müller-Hill. 1988. Recognition helices of lac and $\lambda$ repressor are oriented in opposite directions and recognize similar DNA sequences. Proc. Natl. Acad. Sci. 85: 79477951.

Majumdar, A. and S. Adhya. 1984. Demonstration of two operator elements in gal: In vitro repressor binding studies. Proc. Natl. Acad. Sci. 81: 6100-6104.

Majumdar, A., S. Rudikoff, and S. Adhya. 1987. Purification and properties of gal repressor: $\mathrm{p} L$-galR fusion in $\mathrm{pKC} 31$ plasmid vector. J. Biol. Chem. 262: 2326-2331.

Miller, J.H. 1972. Experiments in molecular genetics. Cold Spring Harbor Laboratory Press, Cold Spring Harbor, New York.

1978. The lacI gene. In The operon (ed. J.H. Miller and W.S. Reznikoff), pp. 31-88. Cold Spring Harbor Laboratory Press, Cold Spring Harbor, New York. 
Mitchell, P.J. and R. Tjian. 1989. Transcriptional regulation in mammalian cells by sequence-specific DNA-binding proteins. Science 245: 371-378.

Monod, J., G. Cohen-Bazire, and M. Cohn. 1951. Sur la biosynthèse de la $\beta$-galactosidase (lactase) chez E. coli. La spècificité de l'induction. Biochim. Biophys. Acta. 7: 585-599.

Mossing, M.C. and M.T. Record. 1986. Upstream operators enhance repression of the lac promoter. Science 233: 889-892.

Nikaido, H. 1961. Galactose sensitive mutants of Salmonella. II. Bacteriolysis induced by galactose. Biochim. Biophys. Acta 48: 460-469.

Oehler, S., E.R. Eismann, H. Krämer, and B. Müller-Hill. 1990. The three operators of the lac operon cooperate in repression. $E M B O J$. (in press).

Ptashne, M. 1986. Gene regulation by proteins acting nearby and at a distance. Nature 322: 697-701.

Reznikoff, W.S., R.B. Winter, and C.K. Hurley. 1974. The location of the repressor binding sites in the lac operon. Proc. Natl. Acad. Sci. 71: 2314-2318.

Reznikoff, W.S., D.A. Siegele, D.W. Cowing, and C.A. Gross. 1985. The regulation of transcription initiation in bacteria. Annu. Rev. Genet. 19: 335-3897.

Schlief, R. 1988. DNA looping. Science 240: 127-128.

Straney, S.B. and D.M. Crothers. 1987. Lac repressor is a transient gene-activating protein. Cell 51: 699-707.

Valentin-Hansen, P., B. Albrechtsen, and J.E. Loøve Larsen. 1986. DNA-protein recognition: Demonstration of three genetically separated operator elements that are required for repression of the Escherichia coli deoCABD promoters by the DeoR repressor. EMBO I. 5: 2015-2021.

Whitson, P.A. and K.S. Matthews. 1986. Dissociation of the lactose repressor-operator DNA complex: Effects of size and sequence context of operator-containing DNA. Biochemistry 25: $3845-3852$.

Williams, R. 1977. Use of polylysine for adsorption of nucleic acids and enzymes to electron microscope specimen films. Proc. Natl. Acad. Sci. 74: 2311-2315.

$\mathrm{Wu}$, J., and D.M. Crothers. 1984. The locus of sequence-directed and protein-induced DNA bending. Nature 308: 509513.

Zwieb, C., J. Kim, and S. Adhya. 1989. DNA bending by negative regulatory proteins: Gal and Lac repressors. Genes Dev. 3: $606-611$. 


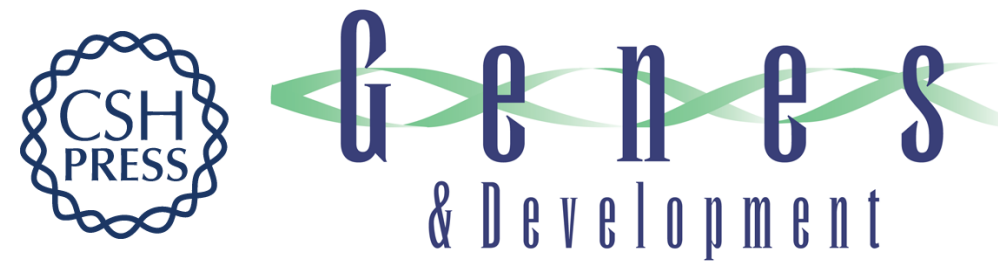

\section{DNA looping in cellular repression of transcription of the galactose operon.}

N Mandal, W Su, R Haber, et al.

Genes Dev. 1990, 4:

Access the most recent version at doi:10.1101/gad.4.3.410

References This article cites 38 articles, 14 of which can be accessed free at:

http://genesdev.cshlp.org/content/4/3/410.full.html\#ref-list-1

License

Email Alerting

Service

Receive free email alerts when new articles cite this article - sign up in the box at the top right corner of the article or click here.

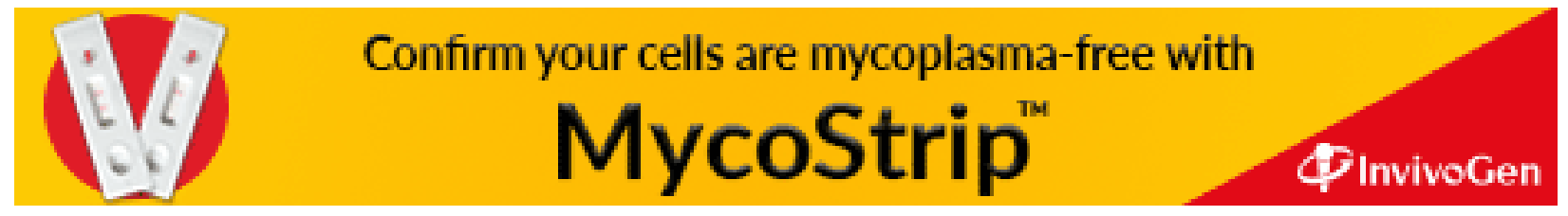

